\title{
Aerobiological studies with special reference to airborne basidiospores of Ganoderma Karst. at Pune, Maharashtra, India.
}

Thakur Vaishali A.

Post Graduate Department of Botany, Fergusson College, Pune-411004, Maharashtra, India.

Received: 4/9/2018; Revised: 4/23/2018; Accepted: 4/29/2018

\begin{abstract}
The basidiospores of Ganoderma were trapped in abundance during the aerobiological studies at Pune, during the year 2012. The sampling was conducted during the rainy months from $18^{\text {th }}$ June to $10^{\text {th }}$ September. Volumetric continuous Tilak Air sampler was used for sampling. Maximum number of spores was observed in the month of August $\left(25760 / \mathrm{m}^{3}\right.$ of air), followed by September $\left(16548 / \mathrm{m}^{3}\right.$ of air). The total spore number was $47460 / \mathrm{m}^{3}$ of air. The highest spore catch $\left(3472 / \mathrm{m}^{3}\right.$ of air) was recorded on $1^{\text {st }}$ September. The relationship between the airborne concentration of Ganoderma spore count and meteorological factors are discussed in the paper. This information could be important for the sensitive individuals as Ganoderma spores are known to be allergic.
\end{abstract}

Keywords: Airspora, Ganoderma, Meteorological factors, Pune, Rainy months, Tilak air sampler.

\section{Introduction}

In rainy months, many types of basidiospores varying from hyaline to coloured and small to large in size have been reported during aerobiological sampling. In earlier aerobiological studies the emphasis was given to the spores of hyphomycetes and ascomycetes. In many aerobiological studies all the basidiospores were kept under the common group 'basidiospores' due to difficulty in identification at genus level. Among such basidiospores, spores of Ganoderma were trapped in large quantity.

Basidiospores of Ganoderma, a member of class basidiomycotina usually known as bracket fungus or wood decay fungus (Horner et al., 1992). It is reported as an important and prevalent genus of fungal airspora throughout the world (Levetin 1990, 1991; Hasnain 1993; Halwagy 1994; Li \& Kendrick 1994, 1995). The allergenic significance of basidiospores and basidiospores of Ganoderma was recorded throughout the globe. Gregory \& Hirst (1952) first time reported the rapid fluctuation in hyaline basidiospores concentration and suggested that basidiospores might be associated with respiratory allergy. Various studies established the environmental prevalence and allergenicity of basidiospores (Lopez et al., 1976; Santilli et al., 1985; Lehrer \& Horner 1990; O’Neil et al., 1990; Hasnain et al., 2005).

Studies all over the world have clearly shown Ganoderma spores as dominant fungal air spores and aeroallergens (Tarlo et al., 1979; Hasnain et al., 1984; Craig and Levetin, 2000; Hasnain et al., 2004). Allergenic components of Ganoderma applanatum have been reported by Vijay et al., (1991). Singh et al., (1994) reported sensitization to Ganoderma lucidum in

\section{*Corresponding Author:}

Dr. Vaishali Arun Thakur,

Assistant Professor,

Department of Botany,

Fergusson College, Pune-4, India.

E-mail: thakurvaishali215@gmail.com the atopic population in India. The entire aerobiological study related to group basidiomycetes has been reviewed by Tilak and his colleagues at Aurangabad, India (Tilak et al., 1981).

There are various other reports like this on the airborne nature, diurnal patterns and allergenic significance of basidiospores from European and other countries but very few from India. In most of the reports all types of basidiospores were grouped under common class 'basidiospores'. Therefore, in present study spores of Ganoderma were identified and counted separately. This aerobiological study was carried out with special reference to airborne basidiospores of Ganoderma count, its circadian periodicity and its relation to meteorological factors during rainy season of 2012 at Pune.

\section{Materials and Methods}

The aerobiological study was carried out with the help of volumetric continuous Tilak Air sampler (Tilak \& Kulkarni, 1970). The sampling was carried from 18 $8^{\text {th }}$ June to $10^{\text {th }}$ September 2012 (Rainy season) at Pune. The relationship between the meteorological factors and spore count in the atmosphere was studied.

\section{Results and Discussion}

The basidiospores of Ganoderma are easily recognizable, one celled oval to ellipsoid brown, apex truncate, apiculate, slightly rough, size is about 9-18 x 6-8 $\mu \mathrm{m}$. Spores are double walled with inner golden-brown wall bearing an ornamentation this pierces the outer transparent wall, so the spores appear to have a spiny surface. 
Ganoderma, a perennial form belonging to Hymenomycetes is cosmopolitan in occurrence. It has been estimated that a large specimen of Ganoderma may liberate 20 million spores per minute and this great rate may be maintained for the five or six months from May to September (Buller 1992).

The basidiospores of Ganoderma were recorded regularly and occur abundantly throughout the study period. Their total spore count was $47460 / \mathrm{m}^{3}$ to the total airspora, whereas, the percentage contribution to the total airspora was 7.44 . The spore count was maximum in the month of August $\left(25760 / \mathrm{m}^{3}\right.$ of air) followed by September also in considerable amount (16548/ $\mathrm{m}^{3}$ of air). The analysis of the meteorological factors during these two months showed $26.3^{\circ} \mathrm{C}$ average mean temperature, $80.4 \%$ average relative humidity, $204.6 \mathrm{~mm}$ rainfall and $1.68 \mathrm{~m} / \mathrm{s}$ average wind velocity in August and $24.8^{\circ} \mathrm{C}$ average mean temperature, $84.5 \%$ average relative humidity, 42.4 $\mathrm{mm}$ rainfall and $1.1 \mathrm{~m} / \mathrm{s}$ average wind velocity in September (Table 1, Figure. 1A. and 1 B).
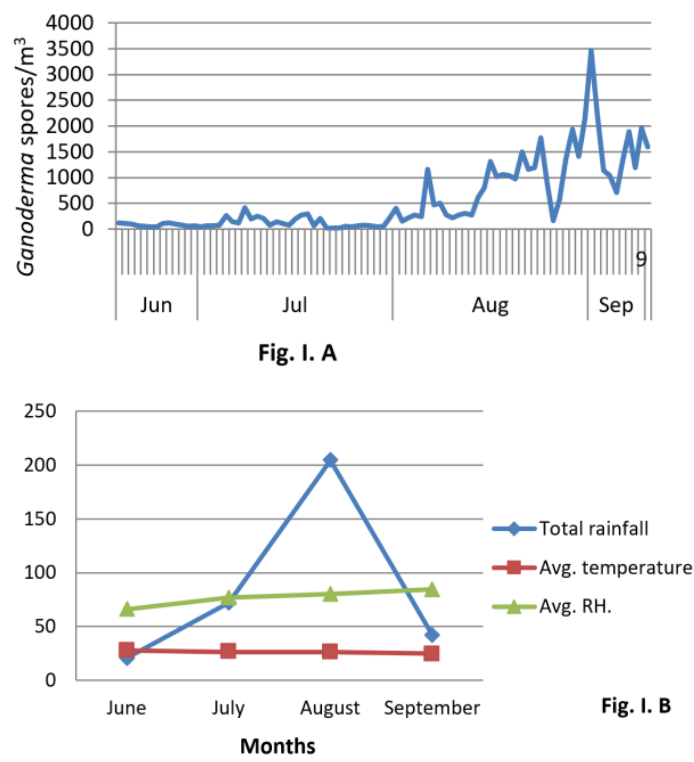

Figure 1. A: Day to day variation in Ganoderma spore count B: Month wise meteorological factors (Temperature, Relative humidity and Rainfall) from $18^{\text {th }}$ June to $10^{\text {th }}$ September 2012 at Pune.

It clearly shows from the present observation that the rainfall or water is a pre-requisite for this fungus to liberate Ganoderma spores into the atmosphere. High relative humidity about $80 \%$ associated with high rainfall appeared to be suitable for this fungus for the production and liberation of the spores in high number into the air. This is somewhat in agreement with the reports of McCracken (1987) and Hasnain et al., (2004) where humidity levels of about $70 \%$ are associated with increased concentrations of Ganoderma spores. Calderon et al., (1995) observed the largest concentrations of Ganoderma spores due to $70-80 \%$ of relative humidity in Mexico City. Lacey (1990) showed an abundance of Ganoderma spores during the rainy period in tropical countries. The rainy period accelerate development of sporocarps and release more spores because of high humidity and water availability.

The highest spore count $\left(3472 / \mathrm{m}^{3}\right.$ of air) was recorded on $1^{\text {st }}$ September 2012 when there was a record of $26^{\circ} \mathrm{C}$ mean temperature, $78.5 \%$ of relative humidity, $17 \mathrm{~mm}$ rainfall and $0.8 \mathrm{~m} / \mathrm{s}$ wind velocity on that day. The total rainfall of $38 \mathrm{~mm}$ was observed on prior two days i.e. $30^{\text {th }}$ and $31^{\text {st }}$ August. It clearly indicates that the rainfall on these prior days helped the fungus to liberate the spores. The relative humidity of $86.5 \%$ was of highest incidence which favored the fungus to release the spores in abundance. The day to day variation in the Ganoderma spore count and the meteorological factors are presented in Figure 1A and 1B.

The spore liberation and concentration of Ganoderma in the atmosphere is increased gradually from June to August as the rainfall progressed and later on started decreasing may be due to low rainfall. The highest spore count in August can be correlated with highest total rainfall associated with high relative humidity and average wind velocity might be responsible for the significant number of Ganoderma spores in the airspora. A clear correlation between the spore liberation, ultimate count in the atmosphere and the meteorological factors had been observed. This observation is more or less similar with the observation of Tilak and Ramchander Rao (1988) who recorded maximum Ganoderma spores in September followed August in rainy season. Singh reported that the maximum Ganoderma spore release occurred during the late summer and autumn, the rainy season in Delhi (Singh et al., 1995).

The mean circadian periodicity curve of basidiospores of Ganoderma has been expressed as the percentage derived from the bihourly catches for 24hour periods (Figure 2). The circadian periodicity studies have indicated that the spore belongs to "Wet spora" and "Night spora" group with a main peak between 2.00 - 4.00 hrs. with subsidiary peaks between 22 to $24 \mathrm{hrs}$. The spore count fluctuated with respect to time and showed gradual decrease and increase in peaks. Then after the main peak there is gradual decrease upto $12 \mathrm{hrs}$ followed by gradual increase upto 24 hrs. (Figure 2). Similar findings have been recorded by Tilak (1989) with its peak at 4.00 hrs. Vittal and Krishnamoorthi (1989) recorded it to night pattern. Craig and Levetin (2000) they recorded diurnal rhythm in Ganoderma spore release with peak at 4.00 hrs. and lowest levels at 16 hrs. at Tulsa, Oklahoma. Hasnain et al., 2004 also showed nocturnal pattern of Ganoderma spores in desert environment of Saudi Arabia. 


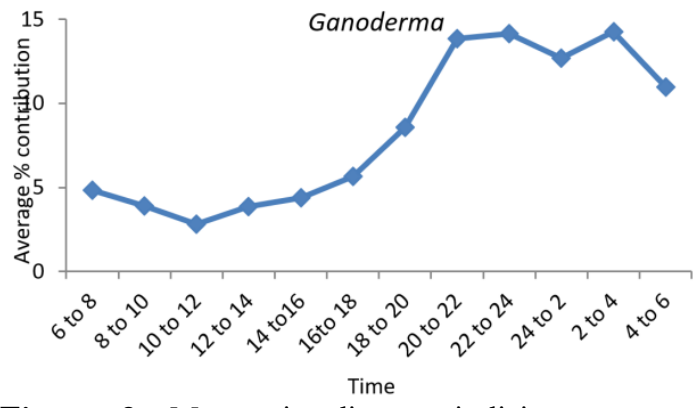

Figure 2. Mean circadian periodicity curve of Ganoderma expressed as the percentage derived from the bihourly catches for 24-hour periods.
The presence of high number of basidiospores of Ganoderma may be important for understanding allergic reactions (Grinn-Gofron \& Strzelczak, 2011). Such aerobiological studies help for understanding of allergic manifestations caused by basidiospores of Ganoderma. Therefore, there is need of continuous study of occurrence of Ganoderma spores in relation to meteorological factors in Pune.

In conclusion, this study showed that airborne basidiospores of Ganoderma spores release depends on high relative humidity associated with rainfall. Hence, we can infer that it belongs to wet spora and showed night pattern. Further annual research data could provide a more accurate variation in spore count over time.

Table I. Month wise count of basidiospores of Ganoderma Karst. in the atmosphere and meteorological factors from $18^{\text {th }}$ June to $10^{\text {th }}$ September 2012.

\begin{tabular}{lccccc}
\hline \multirow{2}{*}{ Month } & \multirow{2}{*}{$\begin{array}{c}\text { Total number of } \\
\text { spores } / \mathbf{~ m}^{\mathbf{3}} \text { of air }\end{array}$} & & \multicolumn{3}{c}{ Meteorological factors } \\
\cline { 3 - 6 } & & $\begin{array}{c}\text { Average mean } \\
\text { temp. }\left({ }^{\circ} \mathbf{C}\right)\end{array}$ & $\begin{array}{c}\text { Average relative } \\
\text { Humidity (\%) }\end{array}$ & $\begin{array}{c}\text { Total rainfall } \\
(\mathbf{m m})\end{array}$ & $\begin{array}{c}\text { Wind velocity } \\
\text { (m/sec.) }\end{array}$ \\
\hline June & 1092 & 27.9 & 66.1 & 20.6 & 3.31 \\
Jul & 4060 & 26.5 & 77.1 & 72.2 & 2.03 \\
Aug & 25760 & 26.3 & 80.4 & 204.6 & 1.68 \\
September & 16548 & 24.8 & 84.5 & 42.4 & 1.1 \\
\hline
\end{tabular}

\section{Acknowledgment}

Author is grateful to U.G.C. for sanctioning fellowship under FIP, The Principal, Fergusson College and Head of Botany Department, Fergusson 7 College, Pune for encouragement, Head, Savitribai Phule Pune University, Pune for providing necessary facilities. Also express sincere thanks to Meteorological Department, Shivaginagar Pune (M.S.) for providing meteorological data. Special thanks to Prof. S.T. Tilak, Dr. S. B. Jogdand, and Dr. S. R. Patil, Y.M. College, Pune for their valuable 9 guidance.

\section{References}

1. Buller, A. H. R. Researches on Fungi. Longmans green \& Co London. (1992): Print.

2. Calderon C., Lacey J., Mccartney, H. A. and Rosas, I Seasonal and diurnal variation of airborne basidiomycetes spore concentration in Mexico City. Grana, 34 (1995): 260-268. Print.

3. Craig, R. L. \& Levetin, E. Multi-year study of Ganoderma aerobiology. Aerobiologia, 16 (2000): 75-81. Online.

4. Gregory, P. H \& Hirst, J. M. Possible role of basidiospores as airborne allergens. Nature, 170 (1952): 414-415. Print.

5. Grinn-Gofroń A. \& Strzelczak A. The effects of meteorological factors on the occurrence of Ganoderma sp. spores in the air. Int J Biometeorol, 55 (2011): 235241. Online.
6. Halwagy, M. H. Fungal airspora of Kuwait City, Kuwait. Grana, 33 (1994): 340-345. Print.

7. Hasnain, S. M. Influence of meteorological factors on the airspora. Grana, 32 (1993): 184-188. Print.

8. Hasnain, S. M., Al-Frayh, A., Khatija, F. and AlSedairy, S. Airborne Ganoderma basidiospores in a country with desert environment. Grana, 43 (2004): 111-115. Print.

9. Hasnain, S. M., Fatima, K., Al-Frayh, A., and AlSedairy, S. T. Prevalence of airborne basidiospores in three coastal cities of Saudi Arabia. Aerobiologia, 21 (2005): 139-145. Print.

10. Hasnain, S. M., Newhook, F. J., Wilson, D. J. and Corbin, J. B. First report of Ganodermaallergenicity in New Zealand. N. Z. J. Sci., 27(1984): 261-267. Print.

11. Horner, W. E., Carol, E., O’Neil, C. E. \& Lehrer, S. B. Basidiospore aeroallergens. Clin. Rev. Allergy, 10 (1992): 191-211. Print.

12. Lacey, J. Aerobiology and health; the role of airborne fungal spores in respiratory diseases. [In:] D. L. Hawksworth (ed.), Frontiers in Mycology. CBA, Wallingford, (1990): 131-156. Print.

13. Lehrer, S. B. \& Horner, W. E. Allergic reactions to basidiospores: Identification of allergens. Aerobiologia, 6 (1990): 181-186. Print.

14. Levetin, E. Identification and concentration of airborne basidiospores. Grana, 30 (1991): 123-128. Print. 
15. Levetin, E. Studies on airborne basidiospores. Aerobiologia, 6 (1990): 177-180. Print.

16. Li, D. W. \& Kendrick, B. A year-round outdoor 24 . aeromycological study in Waterloo, Ontario, Canada. Grana, 34 (1995): 199-207. Print.

17. Li, D. W. \& Kendrick, B. Functional relationships between airborne fungal spores and environmental factors in Kitchener - Waterloo, Ontario, as detected by Canonical correspondence analysis. Grana, 33 (1994): 166-176. Print.

18. Lopez, M. L., Salvaggio, J. E. \& Butcher, B. T. Allergenicity and immunogenecity of basidiomycetes. J. Allergy Clin. Immunol. 57 (1976): 480-488. Print.

19. McCracken, F. L. Factors affecting the spore release of Ganodermaapplanatus. J. MI Academic Science, 32 (1987): 55-60. Print.

20. O' Neil, C. E., Horner, W. E., Reed, M. A., Lopez, M. \& Lehrer, S. B. Evaluation of basidiomycete and deuteromycete (fungi imperfecti) extracts for shared allergenic determinants. Clin. Exp. Allergy, 20 (1990): 533-538. Print.

21. Santilli, J., Rockwell, W. J. \& Collins, R. P. The significance of the basidiomycetes (mushrooms and their allies) in bronchial asthma and allergic rhinitis. Ann. Allergy, 55 (1985): 469-471. Print.

22. Singh A.B., Gupta S. K., Pereira B. M. J. and Prakash D. Sensitization to Ganoderma lucidum in patients with respiratory allergy in India. Clin. Exp. Allergy 25 (1995): 440-447. Print.

23. Singh, A. B., Gupta, S. K., Pereira, B. M. \& Prakash, D. Sensitization to Ganodermalucidum in patients with respiratory allergy in India. Clin. Exp. Allergy, 25 (1994): 440-447. Print.

Tarlo, S. M., Bell, B., Srinivasan, J., Dolovich, J. \& Hargreave, F. E. Human sensitization to Ganoderma antigen. J. Allergy Clin. Immunol., 64 (1979): 43-49. Print.

25. Tilak, S. T. and Ramchander Rao, K. S. Atmospheric concentration of the basidiospores of Ganoderma Karst. IJA, 1. 1(1988): 17-21. Print.

26. Tilak, S. T. Atlas of airborne pollen and fungal spore. VaijayantiPrakashan, Aurangabad, 1 (1989): pp 316. Print.

27. Tilak, S. T., \& Kulkarni, R. L. A new Air sampler. Experientia, 26.4 (1970): 443-444. Print.

28. Tilak, S. T., Saibaba, M. Pillai, S. G. \&Bhasale, S. S. Aeromycology at Aurangabad -V. Basidiomycetes. Proc Nat ConfEnv Bio, 1 (1981): 49-54. Print.

29. Vijay, H. M., Comtois, P., Sharma, R. \& Lemieux, R. Allergenic components of Ganoderma applanatum. Grana, 30 (1991): 167-170. Print.

30. Vittal, P. B. R. and Krishnamoorthi, K. Circadian and seasonal periodicities of some mold allergens in the atmosphere of Madras city (India). Proc. Indian Acad. Sci. (Plant Sci). 99.3 (1989): 247-251. Print.

\section{Cite this article as:}

Thakur Vaishali A. Aerobiological studies with special reference to airborne basidiospores of Ganoderma Karst. at Pune. Annals of Plant Sciences 7.4 (2018) pp. 2209-2212.

do $\mathrm{http}: / / \mathrm{dx}$.doi.org/10.21746/aps.2018.7.5.1

Source of support: U.G.C., New Delhi, India. Conflict of interest: Nil 